\title{
DESIGN OF AN ALTERNATIVE LATERAL LINE FOR FEEDING A DISTRICT DISTRIBUTION NETWORK FROM A NIGERIAN SOUTH WESTERN GRID.
}

\author{
Adeloye A.A ${ }^{1}$ \\ Department of Electrical and Electronic Engineering, School of Engineering, The Federal Polytechnic, Ado-Ekiti, Ekiti State, \\ Nigeria $^{1}$ \\ Melodi A.O ${ }^{2}$ \\ Department of Electrical and Electronic Engineering, School of Engineering and Engineering Technology, Federal University of \\ Technology, Akure, Ondo State, Nigeria ${ }^{2}$ \\ DOI: $10.31364 / S C I R J / v 7 . i 7.2019 . P 0719677$ \\ http://dx.doi.org/10.31364/SCIRJ/v7.i7.2019.P0719677
}

\begin{abstract}
Electrical networks can be classified, territorially, into national, district, local grids with each section of the electric power system (EPS) possessing its unique voltage transfer capabilities and protection schemes. A peculiarity with the safety scheme of a typical district network is the inclusion of alternatives power transfer laterals and protective elements as backup in event of a failure occurrence or the need for routine maintenance to be conducted on the primary distribution network. This publication reveals the design of an alternative route for feeding Akure district distribution network from the existing national electric power grid. A separate Osogbo-Akure $132 \mathrm{kV}$ transmission lateral and tee-off from the Osogbo-Benin $330 \mathrm{kV}$ transmission line were closely examined as potential alternative routes for
\end{abstract} Akure distribution network. Thereafter, a proposed substation was designed and the required circuit elements were sized. Subsequently, a Bill of Engineering Measurement and Evaluation (BEME) was prepared for alternative laterals examined. The latter of the options was selected as a most viable based on the projected construction cost of $\$ 1,283,442,796$ executable within a duration of 6 months. The implementation of this alternative route will enhance the optimization of the power transfer capability of the national EPS and will also improve the economic landscape of South-Western Nigeria.

Keywords: Electric power system (EPS), voltage transfer, protection scheme, transmission laterals, distribution network, Bill of Engineering Measurement and Evaluation (BEME)

\section{INTRODUCTION}

In 1964, a western electric power network was created along Lagos-Ibadan-Ilorin with extensions at Abeokuta, Osogbo, Akure, Benin and Sapele. The Osogbo-Akure $132 \mathrm{kV}$ annex of the western network spans 93 kilometres in route length. It passes through Kajola, Idominasi and Ilesha towns in Osun State. The transmission line continues through Igbara-Oke in Ondo State and eventually terminates in Akure [1] [2] [3]. The conductor type is Aluminium Conductor Steel Reinforced (ACSR) and the entire length is paired, in conformity to regulation that recommends duplication of transmission lines for the purpose of ensuring continuity of electric power supply . It is a single circuit radial line that is supported by 366 steel towers. This network provides bulk electric power to domestic commercial and industrial load points in Akure metropolis. Over the years, the population size of Akure has expanded from 324,000 [4] to 1,800,000 [5] Immigration of inhabitants 
has given rise for an increase in cottage industries, production lines and residential buildings, resulting in a significant rise in the load demand in Akure to approximately 80 MVA [1] [4].

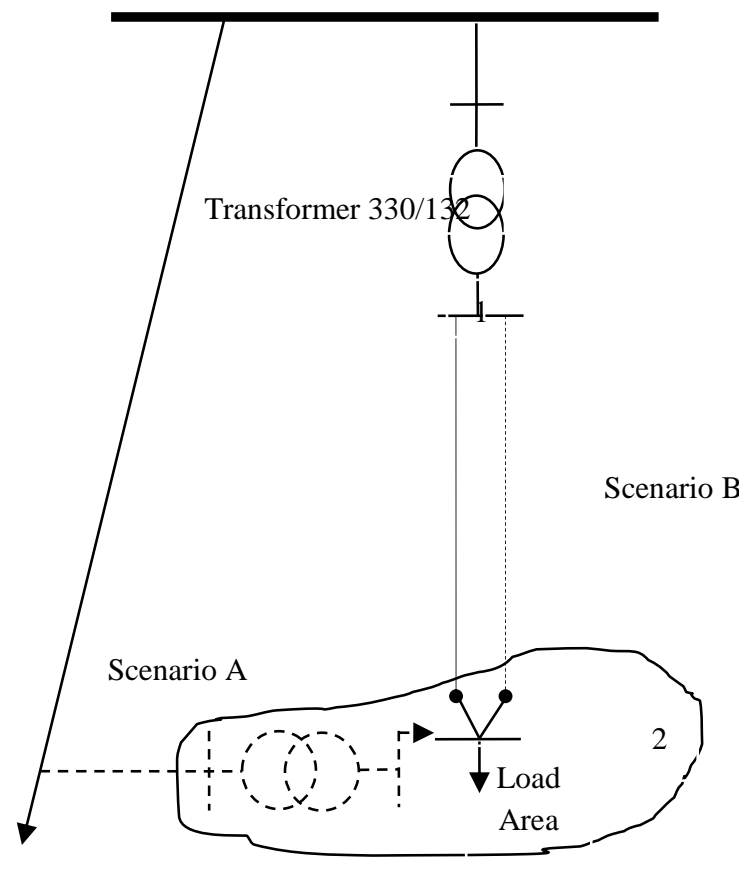

Figure 1: Technical-Economical Model of Prevailing Grid Scenarios of Power Transmission Capacity Reinforcement for a Sub-regional Load.

Sub-transmission systems are those circuits that supply ditribution substations [6] [7]. Distribution circuits are occasionally supplied by high-voltage transmission line. Such high voltages make for expensive high-side equipment in a substation [8] [9]. Sub-transmission circuits are normally supplied by bulk transmission lines at sub-transmission substations [9] [10]. For some utilities, one transmission system serves as both the sub-transmission function (feeding distribution substations) and the transmission function (distributing power from bulk generators) [11] [12]. There is much crossover in functionality and voltage [13]. One utility may have a $132 \mathrm{kV}$ sub-transmission system supplying $11 \mathrm{kV}$ distribution substation [14] [15] . Another utility may have a $33 \mathrm{kV}$ distribution system fed by a $330 \mathrm{kV}$ sub-transmission system [16] [17]. And within utilities, one can find a variety of different voltage combinations [18] [19]. Of all of the subtransmission circuit arrangements, a radial configuration is the simplest and least expensive [20] [21]. Scenario 1, a single source radial circuit like the Osogbo-Akure $132 \mathrm{kV}$ transmission line, provides a more unreliable supply compared to Scenario 2 - double source radial circuit. A fault occurrence either at the bulk power source of a single-source radial circuit, or along its length can force an interruption of several distribution substations or service to many customers [12] [22] [21].

\section{METHODOLOGY}

Two alternative sources of electric power supply were considered for Akure district distribution network. One was an Osogbo-Benin $330 \mathrm{kV}$ transmission line while the other was a separate Osogbo-Akure $132 \mathrm{kV}$ transmission line. These options selected were examined based on their proximity to Akure metropolis and their present load capacity [23] [13] [7].

2.1 Tee-off from the Osogbo-Benin $330 \mathrm{kV}$ transmission line

Osogbo-Benin $330 \mathrm{kV}$ transmission line passes through Akure town and is approximately 95 meters from the existing $132 \mathrm{kV}$ substation. The summary of the present average load supplied to Benin $330 \mathrm{kV}$ switching substation every month is $152,552,000 \mathrm{kWh}$ while the average amount of electric energy it dispatches is $83,142,000 \mathrm{kWh}$ [1] [3]. This implies that it has a surplus of $69,410,000 \mathrm{kWh}$. This quantity of electrical energy is about four times the average monthly load requirement at the Akure distribution network [14] [24]. The cost and items required to tee-off from Osogbo-Benin transmission line and run a short length connection to the existing substation is listed in Table 1. This can be executed within a period of 6 months. A similar connection was executed in Aba in 2008 within this period [2] [20] [25].

\subsection{A Separate Osogbo-Akure $132 \mathrm{kV}$ Transmission Line} Another viable option of an alternative source of electric power supply to Akure is another $132 \mathrm{kV}$ transmission line erected from Osogbo. Its source is about $93 \mathrm{~km}$ from Akure [4] [5] [26]. There are two transformers currently serving Akure feeder are transformers 4T6-150 MVA and 4T2-90 MVA with loading capacities of $97.08 \%$ and $96.67 \%$ respectively [2] [3]. A third transformer 4T1-150 MVA was recently replaced after an explosion incidence and its presently serving as redundancy [3]. The three transformers can be engaged in parallel for the purpose of sustaining an increased load demand on Akure district distribution system through another $132 \mathrm{kV}$ 
transmission line [27] [1] [8]. The cost and items required to install another Osogbo-Akure $132 \mathrm{kV}$ transmission line is listed in Table 2. This option can be executed within 20 months duration. The following considerations were upheld for the design of the proposed 330/132 $\mathrm{kV}$ substation transformer:

a) Two transformers shall be installed in parallel to service the substation by reliability requirement.

b) Each of these transformers shall share equally the designed substation connected load current at normal steady-state operating mode.

c) Each transformer shall be capable of carrying the load demand of the demand centre in case of the failure of one- (n-1 contingency) [20] [14] [23]

The proposed transformer selection was made from the design capacity computation. The transformer capacity $S_{T}$ was selected using Eq. 1 [28].

$S_{T} \geq \frac{S_{\max 2}}{1.2}=\frac{\sqrt{P_{\max 2}^{2}+Q_{\max 2}^{2}}}{1.2}=\frac{78.93}{1.2}$
$=65.78 \mathrm{MVA}$

Where $S_{\max 2}$ is maximum apparent power transmitted; $P_{\max 2}$ is maximum active power component transmitted; $Q_{\max 2}$ is maximum reactive power component transmitted and 1.2 is permissible overload coefficient by thermal requirement. The values of $P_{\max 2}$ and $Q_{\max 2}$ were obtained from Table 4.1. [1]; $P_{\max 2}=68.86, Q_{\max 2}=$ 38.58. The expression in Eq. 1 shows that each transformer's capacity should be greater or equal to $83.33 \%$ of the maximum load. Considering long term load growth projection and available market transformer ratings, $S_{T}=90$ MVA is proposed. The transformer loading coefficient $L C_{T}$ for the two transformers was computed from the terms in Eq. 2.

$$
\begin{aligned}
& L C_{T}=\frac{S_{\max 2}}{n \times S_{T}}=\frac{78.93 M V A}{2 \times 90}=0.44 \\
& <0.8333
\end{aligned}
$$

where $\mathrm{n}$ is numbers of transformers connected in parallel

The result obtained from Eq. 2 implies that the $L C_{T}$ of the two transformers will not exceed $44 \%$. In other words, $56 \%$ of the total capacity of each of the two transformers will be available in event of an increased load demand in Akure metropolis.

In $n-1$ case contingency,

$$
\begin{gathered}
L C_{T, n-1}=\frac{S_{\max 2}}{n \times S_{T}}=\frac{78.93 M V A}{1 \times 90}=0.8 \\
\leq 1.2 \quad 3
\end{gathered}
$$

Result obtained in Equation 3 is less than the permissible overload coefficient by thermal requirement. The proposed 330/132 kV substation was designed as illustrated in Fig.2.

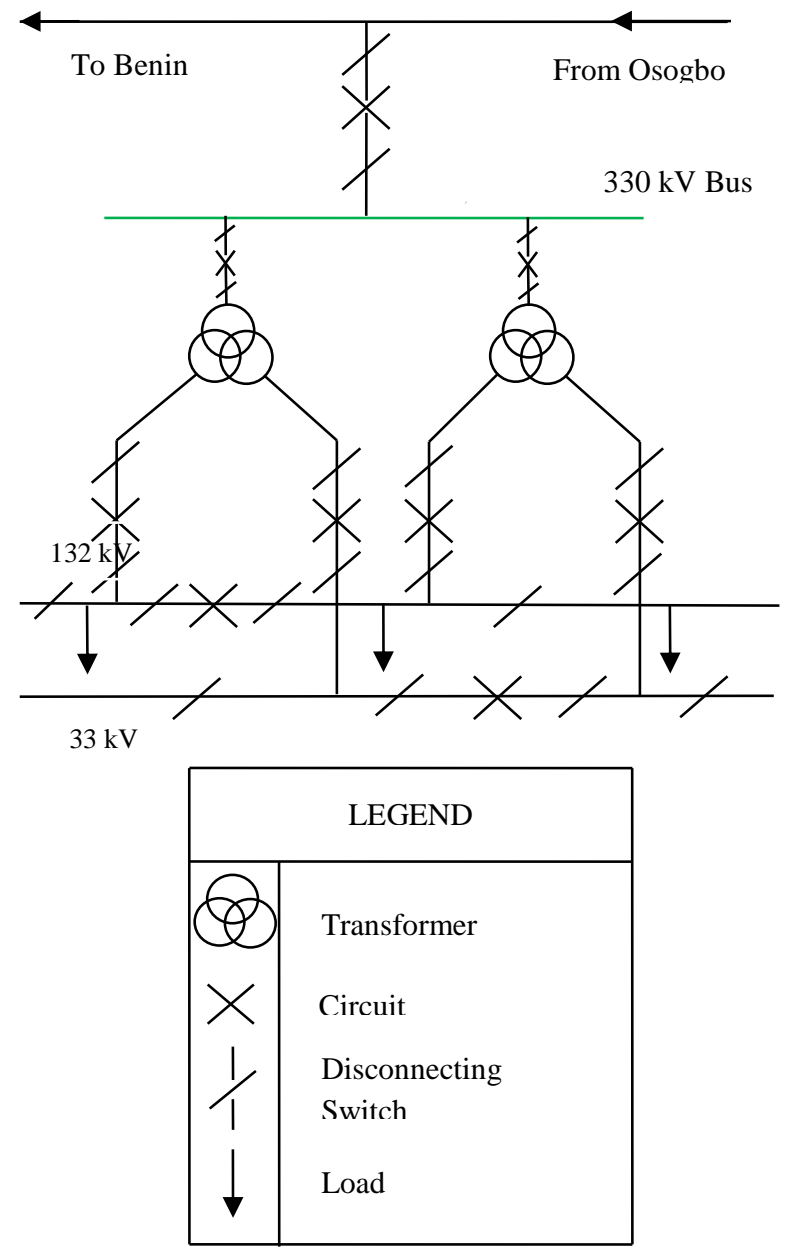

Figure 2 Design of Proposed 330/132 kV Substation

\subsubsection{Sizing of Circuit Breaker (CB)}

A circuit breaker ampacity factor is 2.5 (maximum permissible current) of the circuit or apparatus it is installed to protect. Similarly, the fuse is 1.75 (maximum permissible current) for time delay (NEC 430-152, 2008) [29]. Lower multiplication factor was adopted to allow the breaker or fuse to be closer to starting and operating 
characteristics, thereby allowing the over current device to trip or melt at lower levels of current. Fuses and circuits breakers were selected based on the nominal current permissible under normal working condition and the amount of current to be interrupted. The circuit breaking capacity was determined by Eq. 4

$I_{N}=\frac{S_{T}}{\sqrt{3} \times U_{N}}=\frac{60 \times 10^{6}}{\sqrt{3} \times 330 \times 10^{3}}$

$=3.499 \mathrm{~A}$

where $I_{N}$ is nominal current; and $U_{N}$ is primary nominal voltage $(330 \mathrm{kV})$

Circuit breaker and isolators are installed in series. Hence, both are expected to permit the same magnitude of current under normal and abnormal conditions. For this reason, the same capacity of circuit breaker was selected [13]. The Payback Period (PBP), a formula used to determine the length of time it will take to recoup the initial amount invested on the proposed project or investment [30] is represented mathematically by Eq. 5 .

$$
\text { Payback Period }=\frac{\text { Initial Investment }}{\text { Annual Cash Flow }}=8.4 \text { years } \quad 5
$$

\section{RESULT}

3.1 The Bill of Engineering Measurement and Evaluation (BEME)

BEME was prepared for each of the two options considered as alternative electric power supply sources for Akure district distribution network. 
TABLE 1. BEME for Proposed Tee-off from the Existing $330 \mathrm{kV}$ Transmission Line

\begin{tabular}{|c|l|r|r|r|}
\hline S/N & \multicolumn{1}{|c|}{ Spec/Brand of Substation Equipment } & $\begin{array}{c}\text { Quan } \\
\text { tity }\end{array}$ & \multicolumn{1}{c|}{$\begin{array}{c}\text { Unit } \\
\text { Cost N }\end{array}$} & \multicolumn{1}{c|}{$\begin{array}{c}\text { Cumm. } \\
\text { Cost N }\end{array}$} \\
\hline 1 & 330/132 kV 150 MVA Transformer (Siemens) & 2 & $484,000,000$ & $968,000,000$ \\
\hline 2 & 75 MVA Reactor & 1 & $3,442,450$ & $3,442,450$ \\
\hline 3 & $330 \mathrm{kV}$ Interposing Voltage Transformer & 3 & $1,452,000$ & $4,356,000$ \\
\hline 4 & Ratio:1500/750/1 A, 1600/800/1A Current Transformer & 12 & $3,442,450$ & $41,309,400$ \\
\hline 5 & $330 \mathrm{kV}$ Circuit Breaker & 6 & $29,841,504$ & $179,049,024$ \\
\hline 6 & $330 \mathrm{kV}$ Isolator with Earth Switch Set & 5 & $4,869,781$ & $24,348,905$ \\
\hline 7 & Control/Relay Panel & 1 & $5,653,725$ & $5,653,725$ \\
\hline 8 & 110 V D.C 400AH Lead Acid Battery Bank & 3 & $4,178,380$ & $12,535,140$ \\
\hline 9 & 110 V D.C 415V 3-phase Battery Charger & 1 & $1,915,739$ & $1,915,739$ \\
\hline 10 & 330 kV Capacitor Voltage Transformer (CVT) & 1 & $1,971,695$ & $1,971,695$ \\
\hline 11 & 330 kV Lightning Arrester & 6 & $1,188,220$ & $7,129,320$ \\
\hline 12 & Base radio (V.H.F) & 1 & $2,662,000$ & $2,662,000$ \\
\hline 13 & Transceivers & 5 & 96,800 & 484,000 \\
\hline 14 & H.F Radio & 2 & $2,420,000$ & $4,840,000$ \\
\hline 15 & Pabx & 3 & $6,050,000$ & $18,150,000$ \\
\hline 16 & 330 kV ANSI 25, Case 4 Synchronizing Check Relay & 2 & $1,107,392$ & $2,214,784$ \\
\hline 17 & 27 kVA 3-phase Stand-by Generator & 1 & $2,537,114$ & $2,537,114$ \\
\hline 18 & 350 mm ${ }^{2}$ Mic-Com Cable Aluminium Conductor & 1 & $2,843,500$ & $2,843,500$ \\
\hline & & & TOTAL & $1,283,442,796$ \\
\hline
\end{tabular}

TABLE 2. BEME for Proposed $132 \mathrm{kV}$ Transmission Line and Substation Equipment

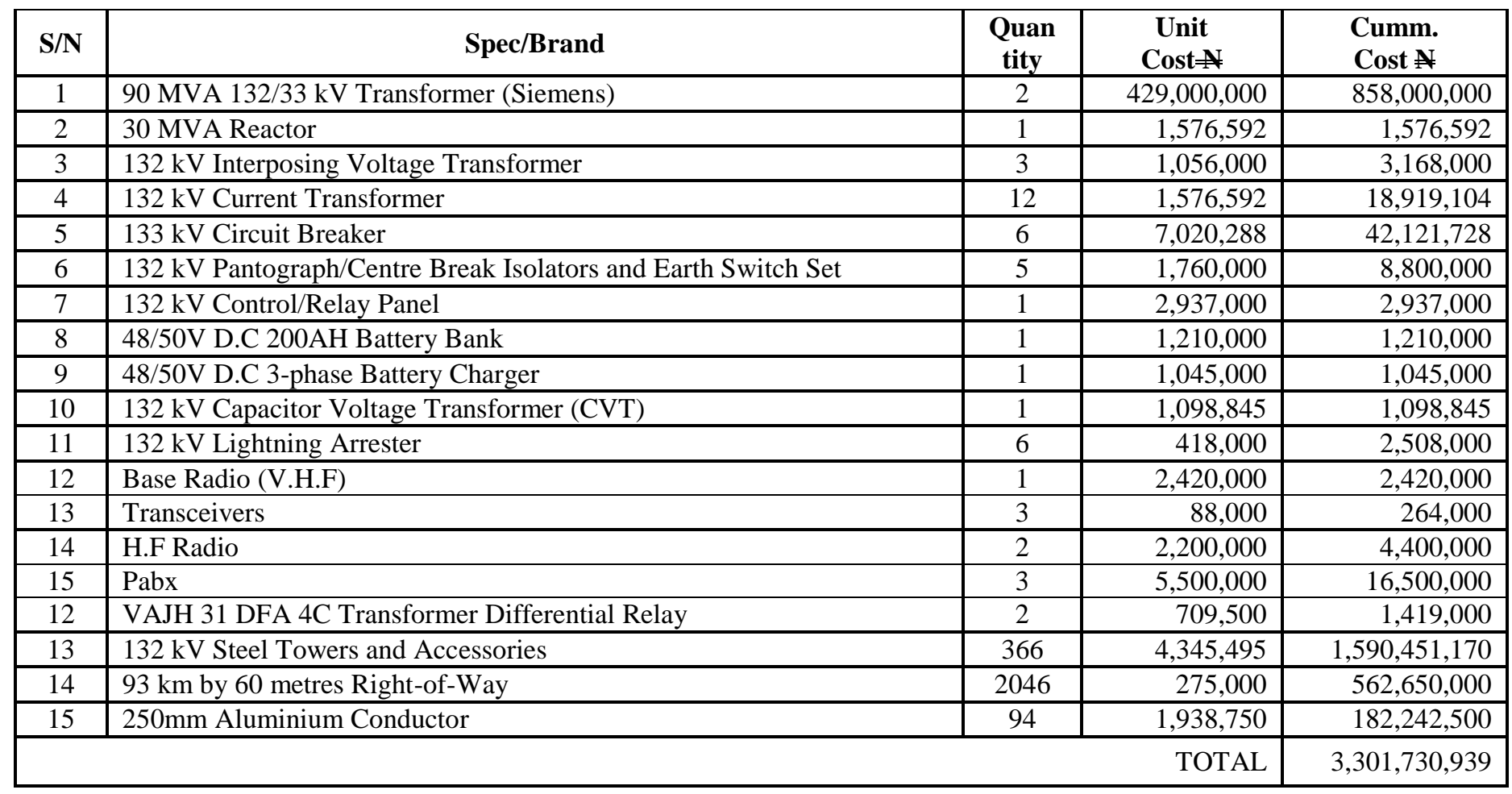




\section{DISCUSSION}

Two options were closely considered as alternative sources of electric power supply to Akure district distribution network. The consideration was based on factors such as proximity to load centres, present load capacity of the sources under consideration, cost of implementation and time schedule of installation. The evaluation conducted revealed a tee-off from the Osogbo-Benin $330 \mathrm{kV}$ transmission line as a preferred choice. This is because there is a surplus of $69,410,000 \mathrm{kWh}$ on the line from which $152,552,000 \mathrm{kWh}-$ an average monthly load demand for Akure metropolis-can be conveniently sourced [1]. Moreover, a total sum of $\$ 1,283,442,796$ will be sufficient to execute the connection within a period of 6 months. With a cumulative annual cash flow of $\$ 120,000,000$ presently recorded by the Nigerian Distribution Companies [31] the initial amount invested on the proposed project will be recouped within a Payback Period (PBP) of 8.4 years. This option is cheap compared to the $\$ 3,301,730,939$ required to connect Akure district distribution network to Osogbo in 20 months duration.

\section{CONCLUSION}

The most feasible and reliable alternative electric power source for Akure district distribution system was identified as a tee-off from the Osogbo-Benin $330 \mathrm{kV}$ transmission line. Assessment reveals that Akure can be connected to this source for the cost of $\$ 1,283,442,796$ in 6 months. This will serve as an optional source of electricity in an event of a fault occurrence at the Osogbo-Akure $132 \mathrm{kV}$ section of the National Control Centre, Osogbo.

\section{REFERENCE}

[1] A. A. Adeloye, Assessment of the Operations of Osogbo-Akure 132 kV Transmission Line, Nigeria, Mauritius: Lambert Academic Publishing, 2018, pp. 68-80.
[2] A. K. S. L. Alex, "Category: Companies of NigeriaNational Electric Power Authority," 26 March 2008. [Online]. Available: http://ww.nigerianwiki.com. [Accessed 22 18:24:53 August 2010].

[3] P. H. C. o. N. PHCN Inventory, "Inventory-Details of Sub station Equipment," 2009.

[4] National Population Commission, "Nigerian Census," Nigerian Census Board, 1991.

[5] I. Ajibefun, "Akure City Profile-Resource Centre on Urban Agriculture and Food Provision," 2012.

[6] B. R. Gupta, Power System Analysis and Design, India: Rajendra Ravindra Printers, Ram Nagar, New Delhi, 2008.

[7] M. E. El-Hawary, "Electrical Energy Systems," in Electrical Energy Systems, Boca Raton, Florida, CRC Press, LLC, 2000, pp. 125-126.

[8] R. C. Dugan, M. F. McGranaghan, S. Surya and W. H. Beaty, Electrical Power Systems Quality,2nd Edition, www.digitallibrary.com: McGraw Hill, 2004.

[9] L. L. Grigsby, Electric Power Engineering Handbook (Power Systems), 2nd Edition, NewYork: Taylor and Francis Group, 2006.

[10] L. L. Grigsby, "Electric Power Generation, Transmission and Distribution, 2nd Edition," in Electric Power Engineering Handbook, www.crcpress.com, CRC Press, 2008, pp. 10, chapter 13 .

[11] L. L. Grigsby, "Power System Stability and Control, 2nd Edition," in Electric Power Engineering Handbook, www.crcpress.com, CRC Press, 2007, pp. 1 , chapter 8.

[12] A. Pabla, "Electric Power Distribution, Fifth Edition," in Electric Power Distribution, Delhi, Tata McGrawHill, 2005, pp. 310-314.

[13] T. Short, "Electrical Power Distribution Handbook," in Electrical Power Distribution Handbook, Boca Raton, Florida, CRC Press LLC, 2004, pp. 44-45.

[14] I. Earth, "Millenium Cities Initiative," 2006.

[15] O. A. Melodi and A. A. Adeloye, "Normal Mode Characteristic Performance Perspective of Model Subtransmission Line in Nigeria Western Grid," Journal for Sustainable Technology, vol. 5, no. 2, pp. 6-9, 2014.

[16] V. Mehta and R. Mehta, "Principles of Power Systems, 4th Revised Edition," in Principles of Power Systems, info@schandgroup.com, S.Chand and Company Limited, 2008, pp. 127-130.

[17] V. Mehta and R. Mehta, Principles of Power Systems, 4th Revised Edition, info@schandgroup.com: S.Chand and Company Limited, 2008.

[18] B. Shirley and N. Shirley, "Gauss-Seidel Power Flow Method," 12 July 2010. [Online]. Available: http//en.wikipedia.org. [Accessed 27 September 2010].

[19] F. Saccomanno, "Electric Power Systems - Analysis and Control," in Electric Power Systems - Analysis and Control, Hoboken, New Jersey, IEEE Press, 2003, pp. $1-4$. 
[20] R. Billinton and R. N. Allan, Reliability Evaluation of Power Systems, 2nd edition, New York: Springer Private Limited, 2008.

[21] H. Saadat, Power System Analysis, India: Tata McGraw-Hill Publishing Company, 2002.

[22] C. Weber, Uncertainty In The Electric Power Industry, New York: Springer Science + Business Media Inc, 2005.

[23] A. Siemens, Electrical Engineering Handbook, Third Edition, New Delhi, India: Mohinder Singh Sejwal for Wiley Eastern Limited, 1998.

[24] V. Ifedi, "Power Holding Company Of Nigeria," 30 July 2010. [Online]. Available: http://en.wikipedia.org. [Accessed 17 20:45:22, August 2010].

[25] J. Cassaza and F. Delea, Understanding Electric Power Systems (by the Institute of Electrical and Electronic Engineers), New Jersey: John Wiley and Sons, Inc., 2003.

[26] A. Daniels, "Electrical Power in Nigeria-Overview," 17 August 2010. [Online]. Available: http://www.mbendi.com. [Accessed 17 20:29:37 August 2010].

[27] G. Allan, "Failure rate," 22 September 2009. [Online]. Available: http//en.wikipedia.org. [Accessed 17 16:28:42, August 2010].

[28] J. Grainger and W. Stevenson, Power System Analysis, New York: McGraw-Hill, 1994.

[29] A. V. Meier, "Electric Power Systems;", in Electric
Power Systems, Hoboken, New Jersey, John Wiley \& Sons, Inc; A Wiley-Interscience publication, 2006, pp. 156-158,166,187,229-233.

[30] J. Irfanullah, “Accounting Explained,” 27 November 2013. [Online]. Available: http;//www.accountingexplained.com.

[31] A. Ejiofor, "Discos Record Revenue Losses Due to Metering Gap, Vandalism,” 26 November 2015. [Online]. Available: www.thisdaylive.com.

[32] E. Lakervi and E. J. Holmes, "Electrical Distribution Network Design," in Reliability, England, Short Run Press Limited., Exeter, 1989, pp. 70-82.

[33] I. Nagrath and D. Kothari, "Power System Engineering," in Power System Engineering, New Delhi, Tata McGraw-Hill Publishing Company Limited, 2001, p. 293.

[34] E. Reeves and M. Heathcote, Newnes Electrical Pocket Book, 23rd edition, Chennai, India: Laserwords Private Limited, 2003. 